\title{
PERANCANGAN HEATSINK UNTUK LAMPU LED MENGGUNAKAN SIMULASI CFD
}

\author{
Rini Anggraini ${ }^{1)}$; Andi F. Sudarma ${ }^{2)}$; Popy Yuliarty ${ }^{3)}$; Fajar V.Enriko ${ }^{4)}$ \\ 1,2,4) Prodi Teknik Mesin, Universitas Mercu Buana, jl.Meruya Selatan No.1 Kembangan Jakbar \\ ${ }^{3)}$ Prodi Teknik Industri, Universitas Mercu Buana, jl.Meruya Selatan No.1 Kembangan Jakbar \\ rini_anggraini@mercubuana.ac.id
}

\begin{abstract}
Abstrak, Artikel ini menampilkan hasil studi secara numeric dari heatsink yang digunakan untuk melepaskan panas dari lampu LED secara konveksi alami.Heatsink terdiri dari tapak lempengan yang berbentuk lingkaran dan terhubung dengan sirip / fin pada salah satu sisinya.Secara umum, aliran dari fluida pada heatsink bergerak secara konveksi alami dimana udara yang lebih dingin mengalir masuk kedalam bagian fin yang lebih panas dan mengalir keluar menuju ujung-ujung sirip. Pada simulasi ini terdapat 3 buah heatsink dengan bentuk yang berbeda (yaitu bentuk persegi, bentuk pin dan bentuk trapesium) dipelajari secara numeric menggunakan perangkat lunak Solidworks untuk mengetahui laju pendinginan yang paling efektif. Hasil simulasi thermal menunjukkan bahwa desain heatsink dengan sirip trapesium menunjukkan temperature maksimal yang terendah yaitu $71,1025^{\circ} \mathrm{C}$, sehingga desain yang direkomendasikan untuk aplikasi dengan konveksi alami adalah sirip trapesium. Luas area permukaan bentuk trapesium lebih besar dibandingkan dengan bentuk persegi dan bentuk pin, yang mempengaruhi efisiensi perpindahan panas pada heatsink
\end{abstract}

Kata Kunci: Perpindahan panas, Heat Sink, CFD, LED, Solidworks Thermal Analysis

\section{PENDAHULUAN}

Industri Lighting dan Elctrical Part saat ini semakin berkembang dan saling bersaing untuk meningkatkan kualitas produk dan desain produk yang menarik untuk kebutuhan interior, arsitektur dan kebutuhan-kebutuhan penggunaan pencahayaan lainnya. Pada masa sekarang lampu LED (light emitting diode) sudah banyak digunakan untuk keperluan rumah tangga sampai dengan industri. LED untuk keperluan rumah tangga lebih cenderung kepada kebutuhan penerangan, misalnya lampu untuk penerangan ruangan sedangkan pada industri diterapkan barang-barang elektronik dan otomotif, misalnya untuk layar televisi dan pada lampu kendaraan. Meskipun harganya relatif mahal, namun lampu LED sangat diminati oleh masyarakat dikarenakan hasilnya lebih terang dan penggunaan dayanya sangat rendah sehingga dapat lebih menghemat energi listrik.

Jenis lampu LED yang banyak digunakan untuk penerangan menggunakan jenis Chip On Board (COB), karena mempunyai cahaya yang terang dan tegangan rendah. Lampu LED menghasilkan panas yang berasal dari chip lampu LED. Timbulnya panas akan mengakibatkan performa dari lampu LED tersebut menurun, bahkan pada tingkat yang lebih serius dapat mengakibatkan lampu LED tersebut mengalami kerusakan. Untuk menjaga agar performa lampu LED tetap baik ada tiga cara di mana suhu junction dapat dikurangi yaitu, pertama adalah dengan membatasi pembentukan panas dalam chip LED, tanpa mengorbankan penerangan, kedua dengan mengadopsi heatsink yang efisien termal dan ketiga dengan mengurangi ketahanan termal dari sistem. Dalam bahasan ini akan memilih cara kedua yaitu, proses pembuangan panas dengan menggunakan heatsink, sedangkan efektifitas heatsink tergantung dari jenisnya. Jenis heat sink yang sering digunakan adalah heatsink jenis Extruded. Bahasan ini cenderung untuk mengetahui karakteristik heatsink yang telah di desain menggunakan metode Finite Element Analysis (FEA). Harapan pada bahasan ini bisa mengetahui desain sirip pendingin heatsink yang mampu menyalurkan panas dengan baik. Heatsink adalah alat untuk menyerap atau membuang panas secara efektif (energi panas) dari lingkungan sekitar (udara) menggunakan permukaan yang diperluas seperti sirip dan duri. Heatsink digunakan dalam berbagai aplikasi di mana pembuangan panas yang efisien diperlukan; contoh utama termasuk pendinginan, mesin panas, dan pendinginan perangkat elektronik. Desain heatsink yang paling umum adalah perangkat logam dengan banyak sirip pendingin, yang disebut sebagai array sirip. 
Kinerja heatsink ditingkatkan dengan meningkatkan baik konduktivitas termal sirip, luas permukaan sirip, atau koefisien perpindahan panas. Profil sirip longitudinal meliputi sirip persegi panjang, segitiga, dan parabola. Profil persegi panjang adalah fundamental dan banyak digunakan terutama dengan arraymulti-sirip. Optimalisasi dari kedua fin dan multiple-finarray dengan konveksi paksa dan konveksi alami di sini disajikan secara rinci untuk profil persegi panjang. Akhirnya, array sirip radial didiskusikan dengan contoh desain.

Ada beberapa karakteristik heatsink :

1. Luas area heatsink akan menyebabkan dispasi panas menjadi lebih baik karena akan memperluas area pendinginan yang dapat mempercepat proses pendinginan yang dapat mempercepat proses pembuangan panas yang diserap oleh heatsink.

2. Bentuk aerodinamik yang baik dapat mempermudah aliran udara panas agar cepat dikeluarkan melalui sirip-sirip pendingin. Khususnya pada heatsink dengan jumlah sirip banyak tetapi dengan jarak antara sirip berdekatan akan membuat aliran udara tidak sempurna sehingga perlu ditambahkan sebuah kipas untuk memperlancar aliran udara pada jenis heatsink tersebut.

3. Transfer panas yang baik pada setiap heatsink juga akan mempermudah pelepasan panas dari sumber panas ke bagian sirip-sirip pendingin. Desain sirip yang tipis memiliki konduktivitas yang lebih baik.

4. Desain permukaan dasar heatsink sampai pada tingkat kedataran yang tinggi sehingga dapat menyentuh permukaan sumber panas lebih baik dan merata. Hal ini dapat menyebabkan penyerapan panas lebih baik,tetapi untuk menghindari resistansi dengan sumber panas heatsink tetap harus menggunakan suatu pasta atau thermal compound agar permukaan sentuh juga lebih merata.

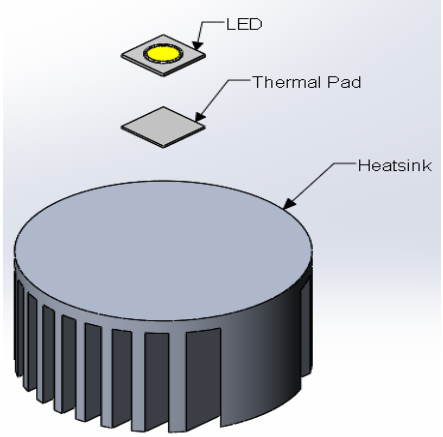

Gambar 1. Gambar skematik pendinginan lampu LED

\section{METODE}

Dunia industri selalu mencari teknologi terbaru untuk meningkatkan kinerja pendinginan pada heat sink dengan biaya rendah. CFD (Computational Fluid Dynamics) adalah salah satu solusi dalam mensimulasikan laju perpindahan panas guna mendapatkan desain yang optimal. Berdasarkan analisa produk yang sudah banyak ada dipasaran, ditemukan ada 3 model sirip yang berbeda di setiap desain heatsink yaitu :

1. Model sirip persegi

2. Model sirip pin

3. Model sirip trapesium

Dari data diatas maka dibuat 3D model heatsink dengan 3 model, yang pertama dengan model sirip persegi, kedua dengan sirip berbentuk pin atau bulat, dan ketiga dengan sirip berbentuk trapesium. Pengukuran jarak kisar dan jumlah sirip pada tiap model hampir sama, hanya saja berbeda model sirip.Informasi detail berikut hasil 3D model yang dibuat menggunakan perangkat lunak Solidworks.

Heatsink sirip persegi dirancang dengan sirip sejajar melalui panjang platform dan tingginya $40 \mathrm{~mm}$, ketebalan sirip adalah 3 $\mathrm{mm}$ dan pitch adalah $7.7 \mathrm{~mm}$. Luas permukaan bersih heatsink adalah $68143 \mathrm{~mm}^{2}$.

Heatsink sirip pin atau bulat dirancang dengan sirip sejajar melalui panjang platform dan tingginya $40 \mathrm{~mm}$, diameter sirip adalah 3 $\mathrm{mm}$ dan pitch adalah $7.7 \mathrm{~mm}$. Luas permukaan bersih heatsink adalah $57555 \mathrm{~mm}^{2}$. 
Sirip heatsink berbentuk trapesium didesain dengan diameter permukaan atas sebesar $80 \mathrm{~mm}$ dan terdapat 13 baris sirip dengan sudut $1,5^{\circ}$ pada tiap area bidangnya. Tinggi keseluruhan heatsink adalah $45 \mathrm{~mm}$ dimana $40 \mathrm{~mm}$ adalah panjang sirip dan $5 \mathrm{~mm}$ adalah base LED, untuk jarak kisar antar sirip adalah $6,4 \mathrm{~mm}$ dan luar permukaan bersih adalah $74481 \mathrm{~mm} 2$.
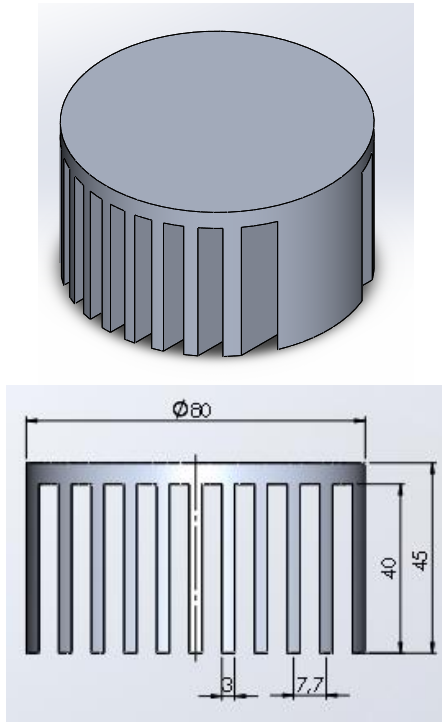

Gambar 2.Heatsink sirip persegi
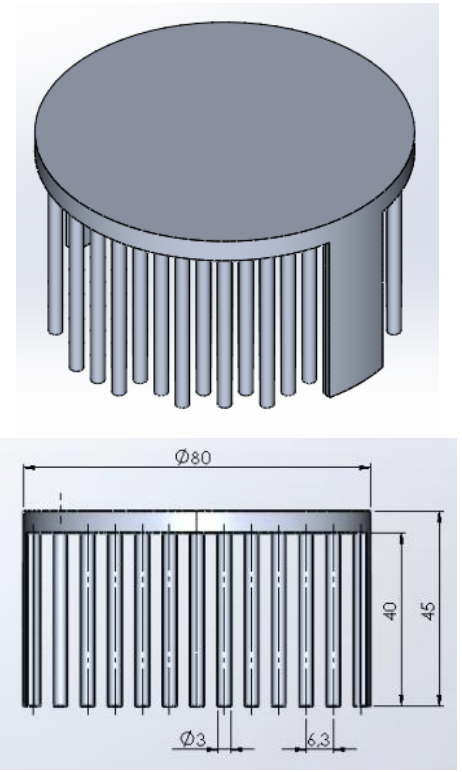

Gambar 3.Heatsink sirip pin

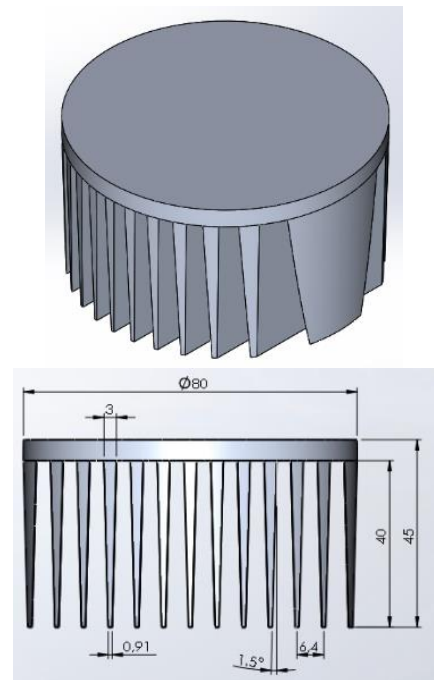

Gambar 4.Heatsink sirip trapezium

Sedangkan material dari kasus perpindahan panas diatas adalah sebagaimana tertulis di dalam Tabel 1.

Tabel 1. Spesifikasi material

\begin{tabular}{|l|l|l|}
\hline & \multicolumn{1}{|c|}{ Heatsink } & \multicolumn{1}{|c|}{$\begin{array}{c}\text { Thermal } \\
\text { Pad }\end{array}$} \\
\hline Material & $\begin{array}{l}\text { alumunium } \\
6063-\mathrm{O}\end{array}$ & $\begin{array}{l}\text { Silicone } \\
\text { carbide }\end{array}$ \\
\hline Panas spesifik & $900 \mathrm{~J} /(\mathrm{kg} . \mathrm{K})$ & $1004 \mathrm{~J} /(\mathrm{kg} . \mathrm{K})$ \\
\hline $\begin{array}{l}\text { Konduktivitas } \\
\text { panas }\end{array}$ & $218 \mathrm{~W} /(\mathrm{m} . \mathrm{K})$ & $4.6 \mathrm{~W} /(\mathrm{m} . \mathrm{K})$ \\
\hline Densitas & $2700 \mathrm{~kg} / \mathrm{m}^{3}$ & $1020 \mathrm{~kg} / \mathrm{m}^{3}$ \\
\hline
\end{tabular}

Pada tabel beban termal, besar panas yang dihasilkan oleh lampu LED adalah $20 \mathrm{~W}$ dengan koefisien konveksi dari heatsink sebesar $10 \mathrm{~W} /\left(\mathrm{m}^{\wedge} 2 . \mathrm{K}\right)$ serta suhu lingkungan adalah $298^{\circ} \mathrm{K}$.

\section{HASIL DAN PEMBAHASAN}

Pada bagian ini, hasil dari simulasi 3 buah heatsink dengan geometri yang berbeda disajikan sebagai berikut. Terdapat tiga jenis heatsink berdasarkan geometrinya, yaitu sirip atau fin persegi, pin dan trapesium. Proses perpindahan panas dari heatsink ke udara dapat dikategorikan sebagai konveksi bebas, dimana udara mengalir secara alami tanpa ada paksaan/tambahan energy dari luar sistem.

Pada gambar 5 ditampilkan distribusi dari panas yang dihasilkan oleh lampu LED. Dari gambar ini terlihat temperatur tertinggi pada LED mencapai $72,87{ }^{\circ} \mathrm{C}$. Sedangkan pada gambar 6 dan 7 menampilkan distribusi panas dari heatsink berbentuk pin dan trapesium dimana menunjukkan temperatur 
tertinggi yaitu $79,2{ }^{\circ} \mathrm{C}$ dan $71,1{ }^{\circ} \mathrm{C}$ secara berurutan.

Pada tabel 1 terlihat bahwa temperature tertinggi dari heat sink berbanding lurus dengan besarnya luas permukaan kontak heat sink dengan fluida. Semakin besar luas bidang kontak maka semakin rendah suhu dari lampu LED.

Hal ini sesuai dengan laju perpindahan konvektif yang merupakan fungsi dari temperature fluida dan permukaan, kecepatan aliran disekitar permukaan dan area permukaan yang berkontak dengan fluida .Sehingga semakin besar bidang kontak fluida dengan permukaan heat sink maka akan semakin meningkat laju perpindahan panas konfektifnya.

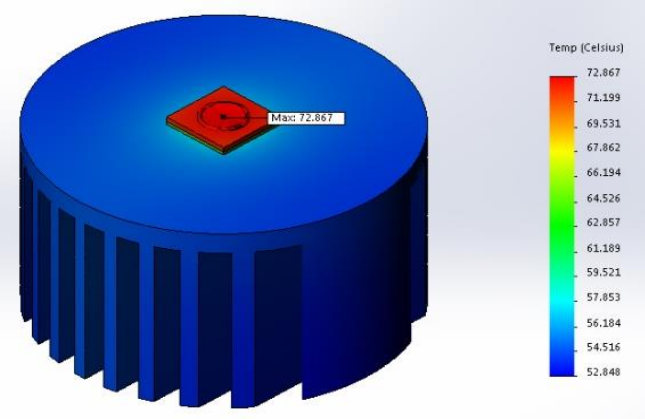

Gambar 5. Hasil simulasi sirip persegi

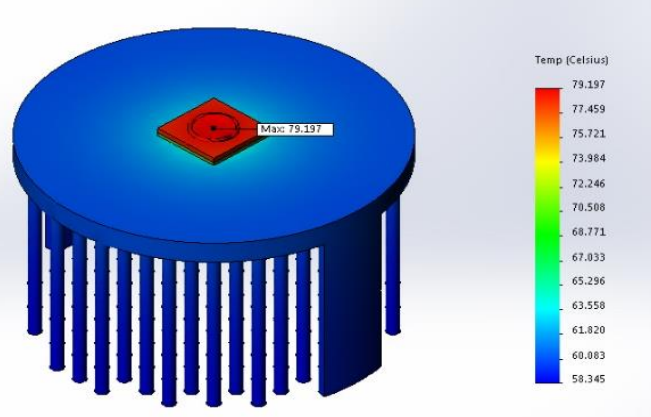

Gambar 6. Hasil simulasi sirip pin.

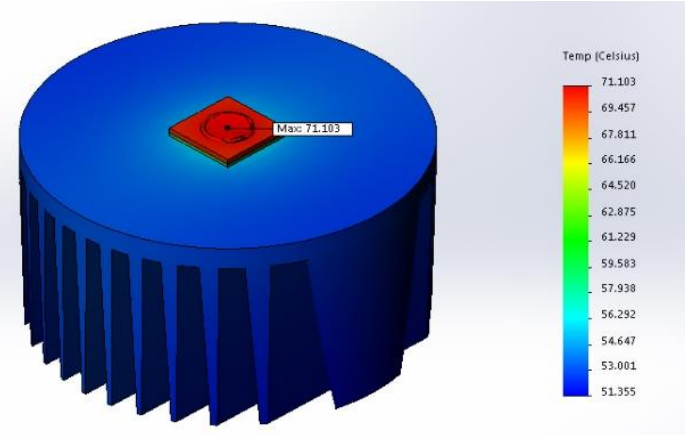

Gambar 7.Hasil simulasi sirip trapesium.
Tabel 2. Pengaruh luas permukaan terhadap temperature maksimum.

\begin{tabular}{|c|c|c|}
\hline $\begin{array}{c}\text { Tipe Sirip } \\
\text { Heatsink }\end{array}$ & $\begin{array}{c}\text { Temperatur } \\
\text { Maksimal } \\
\left({ }^{\circ} \mathbf{C}\right)\end{array}$ & $\begin{array}{c}\text { Luas Area } \\
\text { Permukaan } \\
\left(\mathbf{m m}^{2}\right)\end{array}$ \\
\hline Persegi & 72,8674 & 68.143 \\
\hline Pin & 79,1965 & 57.555 \\
\hline Trapesium & 71,1025 & 74.481 \\
\hline
\end{tabular}

\section{KESIMPULAN}

Berdasarkan apa yang telah ditulis pada babbab sebelumnya, serta hasil simulasi analisis termal pada tiga jenis sirip heatsink yang berbeda, penyusun dapat menyimpulkan sebagai berikut :

1. Pada gambar 5, gambar 6, dan gambar 7 menunjukkan hasil simulasi termal dari 3 desain heatsink. Temperatur maksimal pada heatsink dengan sirip persegi adalah $72,8674^{\circ} \mathrm{C}$, temperatur maksimal pada heatsink dengan sirip pin adalah $79,1965^{\circ}$ $\mathrm{C}$, dan temperatur maksimal pada heatsink dengan sirip trapesium adalah $71,1025^{\circ} \mathrm{C}$. Dari hasil tersebut dapat dilihat bahwa temperatur terendah adalah desain heatsink dengan sirip trapesium, maka jenis desain sirip heatsink yang direkomendasikan untuk aplikasi dengan konveksi alami adalah desain sirip trapesium.

2. Nilai luas area permukaan pada heatsink jenis trapesium lebih besar dibandingkan dengan desain heatsink yang lain. Maka dapat disimpulkan bahwa luas area permukaan mempengaruhi efesiensi perpindahan panas pada heatsink.

\section{DAFTAR PUSTAKA}

Hou Fengze, Yang Daoguo, ZhangGuoqi. (2011). Thermal analysis of LED lighting systemwith different fin heatsinks. Journal of Semiconductors vol 32.

Paul Kurowski. (2015). Thermal Analysis with Solidworks Simulation 2015 and Flow Simulation 2015.

John Wiley \& Sons.(2011).Thermal Design Heat Sinks, Thermoelectrics, Heat Pipes, Compact Heat Exchangers, and Solar Cells. Canada : New Jersey

Mohammad Mehrali.(2015).Effect of specific surface area on convective heat transfer of graphene nanoplatelet aqueous nanofluids. Experimental Thermal and Fluid Science. Vol. 68. 
Nanang Ruhyat, Rahmat Wahyudi. (2015).Pengaruh Variasi Diameter Tube Pipe Evaporator Dengan Circular Fins Terhadap Pressure Drops Aliran Refrigerant Pada Sistem Refrigerasi.Jurnal Sinergi,Jilid 19, Terbitan 1
A.F Sudarma, M.H. Morsy.(2017). Numerical Study on Non-Premixed Air - Methane Swirl Combustor Flows Using RANS Methode, IOP Conference Series, Materials Science and Engineering Volume 453,Conference 1 